\title{
Evaluation of stratospheric chlorine chemistry for the Arctic spring 2005 using modelled and measured OCIO column densities
}

\author{
H. Oetjen ${ }^{1,2}$, F. Wittrock ${ }^{1}$, A. Richter ${ }^{1}$, M. P. Chipperfield ${ }^{3}$, T. Medeke ${ }^{1}$, N. Sheode ${ }^{1}$, B.-M. Sinnhuber ${ }^{1}$, \\ M. Sinnhuber ${ }^{1}$, and J. P. Burrows ${ }^{1}$ \\ ${ }^{1}$ University of Bremen, Institute of Environmental Physics, Germany \\ ${ }^{2}$ University of Leeds, School of Chemistry Leeds, UK \\ ${ }^{3}$ University of Leeds, School of Earth and Environment, Leeds, UK
}

Received: 20 October 2009 - Published in Atmos. Chem. Phys. Discuss.: 10 December 2009

Revised: 21 December 2010 - Accepted: 5 January 2011 - Published: 24 January 2011

\begin{abstract}
Chlorine dioxide, OClO, column amounts retrieved from measurements of the SCIAMACHY satellite instrument are presented and validated by comparison with simultaneous ground-based DOAS observations. In addition, the measurements are compared to model calculations taking into account the photochemical change along the light path.

Although $\mathrm{OClO}$ does not participate directly in the destruction of ozone, its accurate measurement as well as modelling is crucial to understand the highly perturbed chlorine chemistry in the polar vortices. SCIAMACHY OClO slant columns retrieved during spring 2005 have been quantitatively validated by comparison with slant columns retrieved from measurements made in $\mathrm{Ny}$-Ålesund $\left(79^{\circ} \mathrm{N}, 12^{\circ} \mathrm{E}\right)$ and Summit $\left(73^{\circ} \mathrm{N}, 38^{\circ} \mathrm{W}\right)$ as well qualitatively for Bremen $\left(53^{\circ} \mathrm{N}, 9^{\circ} \mathrm{E}\right)$. Fair to good agreement is found depending on location as well as time of year.

OClO slant column densities modelled with a set of stacked box models and considering the light path through the atmosphere are also included in this comparison. The model predictions differ significantly from the measured quantities. $\mathrm{OClO}$ amounts are underestimated for conditions of strong chlorine activation and at large solar zenith angles. Sensitivity studies for several parameters in the stacked box model have been performed and it is inferred that using the chemistry known to date, the observed OClO cannot be adequately reproduced within the range of uncertainties given for the various model parameters.
\end{abstract}

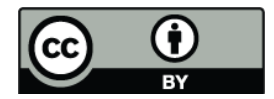

Correspondence to: A. Richter (richter@iup.physik.uni-bremen.de)

\section{Introduction}

One of the most important issues in atmospheric science remains the understanding of the stratospheric ozone depletion, especially, in polar regions and its response to environmental policy and global climate change (WMO, 2007). In the dark, cold polar winter, reservoir chlorine species of primarily anthropogenic origin are converted to radicals or their precursors by means of heterogeneous reactions taking place on the surface of polar stratospheric cloud (PSC) particles. During this process, $\mathrm{NO}_{\mathrm{x}}$ (nitric oxide $\mathrm{NO}$ and nitrogen dioxide $\mathrm{NO}_{2}$ ) is trapped in the $\mathrm{PSCs}$ as nitric acid $\mathrm{HNO}_{3}$ hindering the restoration of reservoir species like chlorine nitrate. The temperature threshold for the formation of PSCs is about $195 \mathrm{~K}$ and hence they can usually only be observed in the winter-time polar stratosphere. The species formed on the particle surfaces are e.g. $\mathrm{Cl}_{2}$ and $\mathrm{HOCl}$. In spring, photolysis releases the chlorine radicals initiating the catalytic destruction of ozone resulting in the so-called ozone hole over the springtime poles (e.g. Chubachi, 1984; Farman et al., 1985). Within this context, the $\mathrm{ClO}-\mathrm{BrO}-$ cycle is an efficient ozone destruction mechanism in the lower polar stratosphere (Yung et al., 1980; McElroy et al., 1986; Lary, 1997). One of the channels of the $\mathrm{BrO}+\mathrm{ClO}$ reaction produces chlorine dioxide $\mathrm{OClO}$ :

$\mathrm{BrO}+\mathrm{ClO} \rightarrow \mathrm{Br}+\mathrm{OClO}$

Reaction (R1) is thought to be the main production mechanism for atmospheric OClO (Friedl and Sander, 1989; Tung et al., 1986) and assuming that the photolysis primarily leads to $\mathrm{O}+\mathrm{ClO}$, this reaction results in a null cycle for ozone destruction. 
The first measurements of atmospheric $\mathrm{OClO}$ were performed by Solomon et al. (1987a) by means of ground-based UV-visible spectroscopy over Antarctica followed by several other studies for the southern hemisphere (e.g. Sanders et al., 1993; Kreher et al., 1996; Frieß et al., 2005) but also for the Arctic (e.g. Solomon et al., 1988; Perner et al., 1994; Gil et al., 1996; Otten et al., 1998; Tørnkvist et al., 2002) and at mid-latitudes (Aliwell et al., 1997; Richter et al., 1999). The same spectroscopic technique has been applied for balloon and air-borne measurements in order to retrieve profile information of OClO (e.g. Wahner et al., 1989; Schiller et al., 1990; Pommereau and Piquard, 1994; Renard et al., 1997; Riviere et al., 2003).

The first satellite-based remote sensing of $\mathrm{OClO}$ became available with the launch of the Global Ozone Monitoring Experiment (GOME-1) in April 1995. These data have been used extensively for OClO studies (Burrows et al., 1999; Wagner et al., 2001, 2002; Kühl et al., 2004a, b; Richter et al., 2005). GOME-1 OClO measurements were followed by observations from the Scanning Imaging Spectrometer for Atmospheric Cartography (SCIAMACHY) on ENVISAT (Kühl, 2005; Kühl et al., 2008) and also by OSIRIS on the Odin satellite (Krecl et al., 2006). Recently, the global presence of night-time $\mathrm{OClO}$ has been detected in stellar occultation measurements performed by the GOMOS instrument which also operates on ENVISAT (Fussen et al., 2006).

Other species of the active chlorine family measured in the stratosphere are chlorine monoxide $\mathrm{ClO}$ through remote sensing (Solomon et al., 2000), and in-situ measurements (e.g. Brune and Anderson, 1986; Pierson et al., 1999; Avallone and Toohey, 2001; Vogel et al., 2003) and its dimer $\mathrm{Cl}_{2} \mathrm{O}_{2}$ (Stimpfle et al., 2004; von Hobe et al., 2005). Extensive measurements of $\mathrm{ClO}$ from space have been provided by the MLS instruments on UARS and AURA and the SMR instrument on Odin (e.g. Barret et al., 2006; Berthet et al., 2005; Santee et al., 2008).

This study focuses on measurements in northern spring 2005. The Arctic winter 2004/2005 was characterised by extremely cold temperatures in the stratosphere (see e.g. Feng et al., 2007a and references therein). In contrast to the previous years of SCIAMACHY observations (see Fig. 1 for a monthly average of the OClO columns), a large and also persistent vortex developed in the northern hemisphere, leading to chlorine activation and large $\mathrm{OClO}$ signals.

The aims of this study are to describe the retrieval of $\mathrm{OClO}$ columns from SCIAMACHY observations, to validate them with ground-based measurements, and to compare modelled and measured $\mathrm{OClO}$ columns. In addition, the origins of the differences between measurements and model have been investigated. The manuscript is organised as follows: Section 2 describes the technique used for retrieving the $\mathrm{OClO}$ columns for the three different data sets. Sections 3 and 4 are dedicated to the validation of the SCIAMACHY OClO columns. The solar zenith angle dependence of the $\mathrm{OClO}$ columns is investigated in Sect. 5. In Sect. 6, the sensitivity
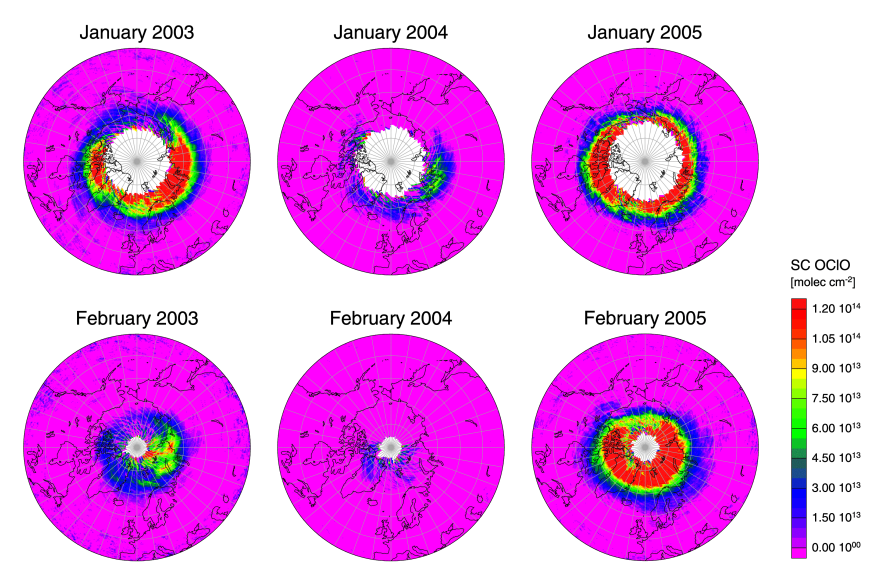

Fig. 1. Monthly averages of $\mathrm{OClO}$ slant column densities retrieved from SCIAMACHY observations over the Arctic for the winters 2003 to 2005, top panel shows averages for January und bottom panels for February for the three consecutive years.

of the chemistry model to various parameters is tested and discussed. This study is then summarised in Sect. 7.

\section{Data sets}

Comparisons of different measurements of OClO with each other or with model predictions require the following issues to be taken adequately into account:

- the photolysis of $\mathrm{OClO}$, which in daylight is rapid,

- the changing column and profile during twilight,

- the change of solar zenith angle (SZA) along the line of sight,

- low signal to noise of the remote sensing of solar scattered radiation at large SZAs.

The comparison is best performed for the slant column densities. The slant column is the absorber density integrated along the light path of the instrument. Although the viewing geometries of the satellite- and ground-based measurements are very different, the air mass factors (AMF), which are the ratio between the slant column densities and the vertical column densities, yield similar values at large solar zenith angles. The AMF modelled for the same vertical profile (model OClO profile for Ny-Ålesund on 4 March, for a description of the models see Sect. 2.3) for the two observation geometries agree within $4 \%$ in the SZA range between $89^{\circ}$ and $91^{\circ}$ and by $\sim 13 \%$ at $80^{\circ} \mathrm{SZA}$. Consequently, the slant column densities of $\mathrm{OClO}$ from the different platforms can be compared directly. The modelled $\mathrm{OClO}$ profiles are also converted to slant column densities for the given observational geometry assuming Arctic background conditions for the aerosol in the radiative transfer calculations. In the following, the three data sets used in this study are described. 


\subsection{SCIAMACHY}

The SCIAMACHY (SCanning Imaging Absorption spectroMeter for Atmospheric CartograpHY) instrument is a spectrometer designed to measure sunlight, transmitted, reflected and scattered by the Earth's atmosphere or surface in the ultraviolet, visible and near-infrared wavelength region $(240 \mathrm{~nm}-2380 \mathrm{~nm})$ at a moderate spectral resolution $(0.2 \mathrm{~nm}-1.5 \mathrm{~nm})$ (Bovensmann et al., 1999; Burrows et al., 1995). SCIAMACHY was launched on ENVISAT into a sun-synchronous orbit on 1 March 2002 having an equator crossing time of 10:00 a.m. local time (descending node). Global coverage is obtained within six days at the equator and within one day at $70^{\circ}$ latitude in spring. The spatial resolution varies between $30 \mathrm{~km} \times 30 \mathrm{~km}$ and $240 \mathrm{~km} \times 30 \mathrm{~km}$ depending on location and season.

Interpretation of the satellite measurements is complicated by the rapid photochemistry of $\mathrm{OClO}$ combined with the sunsynchronous orbit of the satellite. Along the satellite orbit, the solar zenith angle varies with latitude leading to a latitude dependent change in photolysis rates and thus $\mathrm{OClO}$ amounts. In order to facilitate systematic validation with ground-based measurements, the $\mathrm{OClO}$ amounts retrieved from the satellite over the stations are therefore compared with the OClO column measured from the ground at the time of satellite-overpass.

The observed spectra are analysed with the well-known Differential Optical Absorption Spectroscopy (DOAS) method (see e.g. Solomon et al., 1987b). The fitting procedure, in a window from 365 to $389 \mathrm{~nm}$, includes in addition to the OClO cross section (Kromminga et al., 2003) and a polynomial for the compensation of broad-band features, the nitrogen dioxide $\mathrm{NO}_{2}$ (Vandaele et al., 2003), and the oxygen dimer $\mathrm{O}_{4}$ (Hermans et al., 1999) absorption cross sections as well as a rotational Raman scattering cross section (Vountas et al., 1998). A solar irradiance measurement is chosen as the background spectrum. Additional corrections have to be included to account for under-sampling and the polarisation sensitivity of the instrument. As an individual measurement of SCIAMACHY has only a very short exposure time and therefore limited signal-to-noise at low sun, all measurements within $200 \mathrm{~km}$ of a station are averaged over a day. The quality of the resulting $\mathrm{OClO}$ fit is illustrated in Fig. 2. The overall accuracy of the averaged slant columns is estimated to be about $30 \%$ or higher.

\subsection{Ground-based measurements: BREDOM}

The BREDOM (Bremian DOAS Network for Atmospheric Measurements) is a ground-based network of high-quality UV/visible spectrometers for atmospheric observations that has been set up by the Institute of Environmental Physics (IUP), University of Bremen, Germany. The instruments are NDSC/NDACC-approved (Aliwell et al., 2002; Vandaele et al., 2005). The temperature-stabilised spectrome-
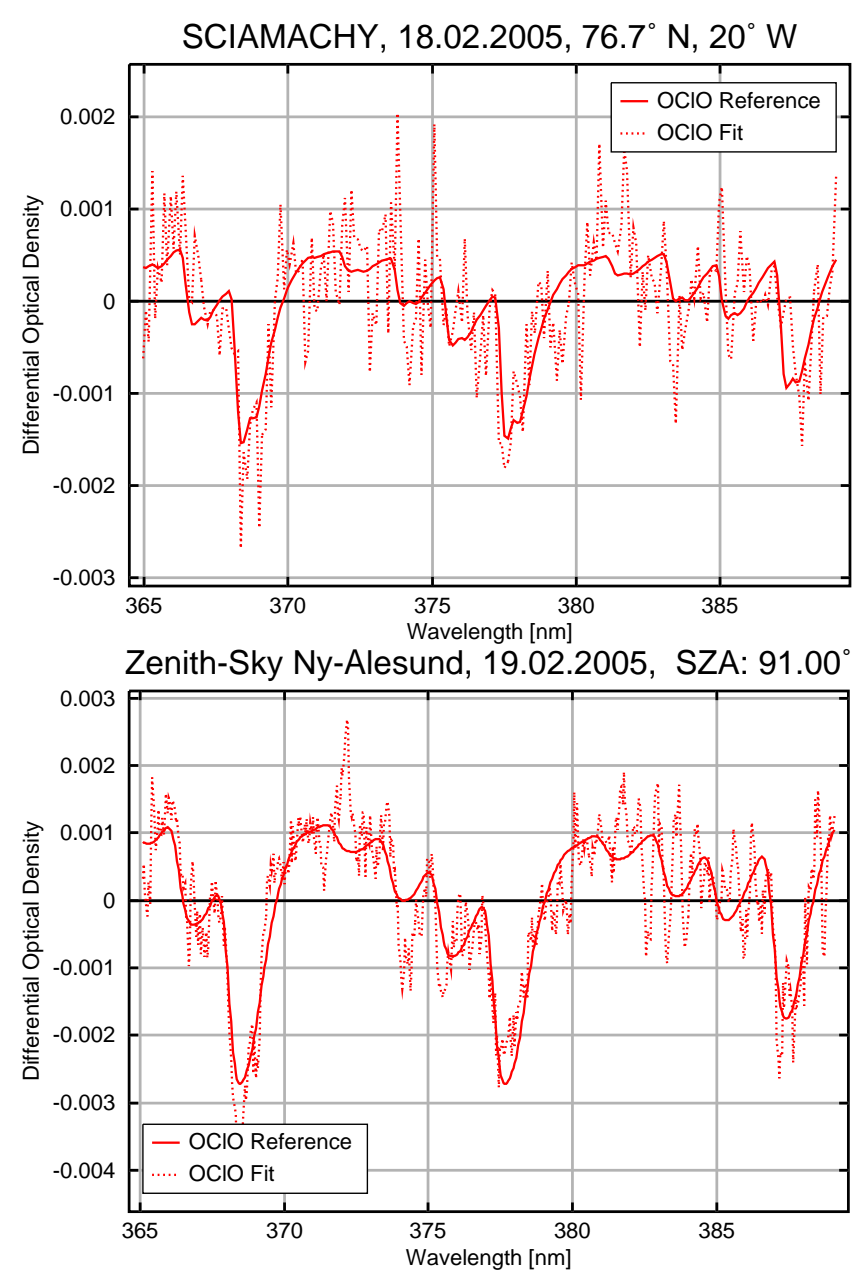

Fig. 2. Example of the OClO retrieval fit for SCIAMACHY (top panel) and for ground-based measurement for $\mathrm{Ny}$-Ålesund (bottom panel).

ters are equipped with cooled CCD detectors. The spectral resolution is $\sim 0.5-0.8 \mathrm{~nm}$ and about 7 to 12 detector pixels cover the full width at half maximum depending on the individual instrumental set-up. The instruments are connected to a multi-axis telescope via a quartz-fibre bundle and are described in more detail elsewhere (Richter et al., 1999; Wittrock et al., 2004; Heckel et al., 2005). In this study, only measurements of light scattered in the zenith are used. The measurement sites include Ny-Ålesund (Svalbard, $79^{\circ} \mathrm{N}, 12^{\circ} \mathrm{E}$ ), Summit (Greenland, $73^{\circ} \mathrm{N}, 38^{\circ} \mathrm{W}$ ), and Bremen (Germany, $\left.53^{\circ} \mathrm{N}, 9^{\circ} \mathrm{E}\right)$.

Similar settings for the retrieval and the same algorithm as for the SCIAMACHY data are applied to the groundbased spectra to retrieve the OClO slant columns. A measurement recorded at a small solar zenith angle is used as the reference or background spectrum for the whole time series i.e. the measurement at a given SZA is divided by this spectrum of scattered solar radiation. It is assumed that there is no $\mathrm{OClO}$ present in the background 
spectrum. A fit example for an $\mathrm{OClO}$ slant column density of about $4 \times 10^{14}$ molecules $\mathrm{cm}^{-2}$ measured in $\mathrm{Ny}$-Ålesund on 19 February is presented in Fig. 2.

The $1 \sigma$ spectral fit error is usually below $5 \%$ at $90^{\circ}$ SZA. This includes uncertainties introduced by spectral interferences of the different absorption cross sections, by the Ring effect, which results in in-filling of Fraunhofer lines and is produced by the inelastic rotational Raman scattering on air molecules, and by the wavelength calibration of the cross sections. The fit error increases towards smaller SZAs. In the following, the $2 \sigma$ error is quoted to account for possible systematic uncertainties, e.g. uncertainties in the absorption cross section of $\mathrm{OClO}$. The uncertainty in the $\mathrm{OClO}$ cross section is estimated to be 7\% (Wahner et al., 1987). The overall accuracy is about $20 \%$ at $90^{\circ}$ SZA. The precision is much better. For most spectra, used in this study, the detection limit is smaller than $5 \times 10^{13}$ molecules $\mathrm{cm}^{-2}$ at $90^{\circ}$ SZA.

\subsection{Modelling}

The ground-based measurements and SCIAMACHY OClO are compared to modelled slant columns. These are calculated in three steps: First of all, the results of the three-dimensional (3-D) chemical transport model SLIMCAT (Chipperfield, 1999) are extracted on a daily basis at 12:00 UT over the stations and thereafter, in a second step, used to initialise a set of one-dimensional (1-D) photochemical stacked box models to obtain absorber profiles for the individual species at high temporal resolution. More details can be found in Sinnhuber et al. $(2002,2005)$ where an almost identical model is used to simulate stratospheric bromine chemistry.

The OClO profiles as a function of solar zenith angle are then used to derive slant column densities for the groundbased observation geometry. This third step is accomplished with the full-spherical radiative transfer model SCIATRAN (Rozanov et al., 2001, 2005), which includes the correct treatment of the photochemistry along the line of sight, i.e. the change of concentration of the absorber with local SZA is taken into account when the light path is simulated. This so-called photochemical enhancement is necessary for photo-labile substances with a short lifetime such as OClO. It has been shown before that SCIATRAN is suitable to interpret ground-based scattered sunlight measurements up to a SZA of $93^{\circ}$ work (Wittrock et al., 2004; Hendrick et al., 2006; Wagner et al., 2007).

In more detail, SCIATRAN simulates the paths of the photons from the sun into the telescope. Along this light path, the SZA changes due to the curvature of the earth. In higher altitudes and towards the sun, the SZA is smaller than the one at the measurement site causing a changing photochemistry for atmospheric trace gases. In SCIATRAN for each local SZA, the corresponding absorber profile from the output of the photochemical model is selected and the absorber den-

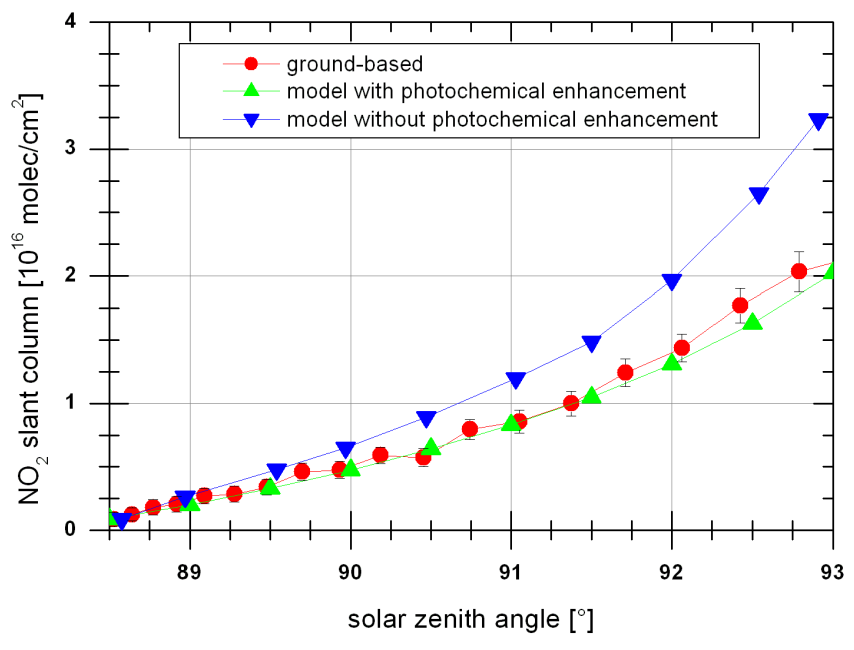

Fig. 3. Measurements (in red) and model calculations of $\mathrm{NO}_{2}$ slant columns at $\mathrm{Ny}$ - $\AA$ lesund $\left(79^{\circ} \mathrm{N}, 12^{\circ} \mathrm{E}\right)$ for 24 February as a function of SZA. The error bars represent the $2 \sigma$ error of the measurements. The model simulations with photochemical enhancement (in green) are smaller than the ones without (in blue) due to the changing SZA along the line-of sight of the measurements.

sity is integrated to yield the column density along the light path. For illustration an example of $\mathrm{NO}_{2}$ slant column densities is presented in Fig. 3. Shown are measurements and simulations for Ny-Ålesund of the afternoon of 24 February. Due to the on average smaller effective SZA, the simulations including the photochemical enhancement result in smaller slant column densities which agree very well with the measurements.

\section{Validation}

In the following comparison, for SCIAMACHY data, all pixels with their centre within a radius of $200 \mathrm{~km}$ around the station are used and then the average SZA is given. The groundbased measurements are averaged over $2^{\circ}$ SZA, i.e. $\pm 1^{\circ}$ SZA around the average SCIAMACHY SZA. The modelled columns on the other hand are calculated at the exact angle. Figure 4 shows the OClO slant columns for spring 2005 over Ny-Ålesund and Summit. Note that the SZA of the SCIAMACHY measurements is changing over the time series since the overpass takes place at a fixed time close to the local noon. Therefore, the variation in $\mathrm{OClO}$ during this time period is mainly caused by the decreasing SZA and the associated increased photolysis rate of OClO.

In Ny-Ålesund in the first two weeks until 25 February with SZAs larger $89^{\circ}$, the agreement between groundbased and satellite-measured OClO columns is only fair with the ground-based instrument in general seeing higher values than the satellite. SZAs are rather large this early in the year and rapid changes in photochemistry take place. The 

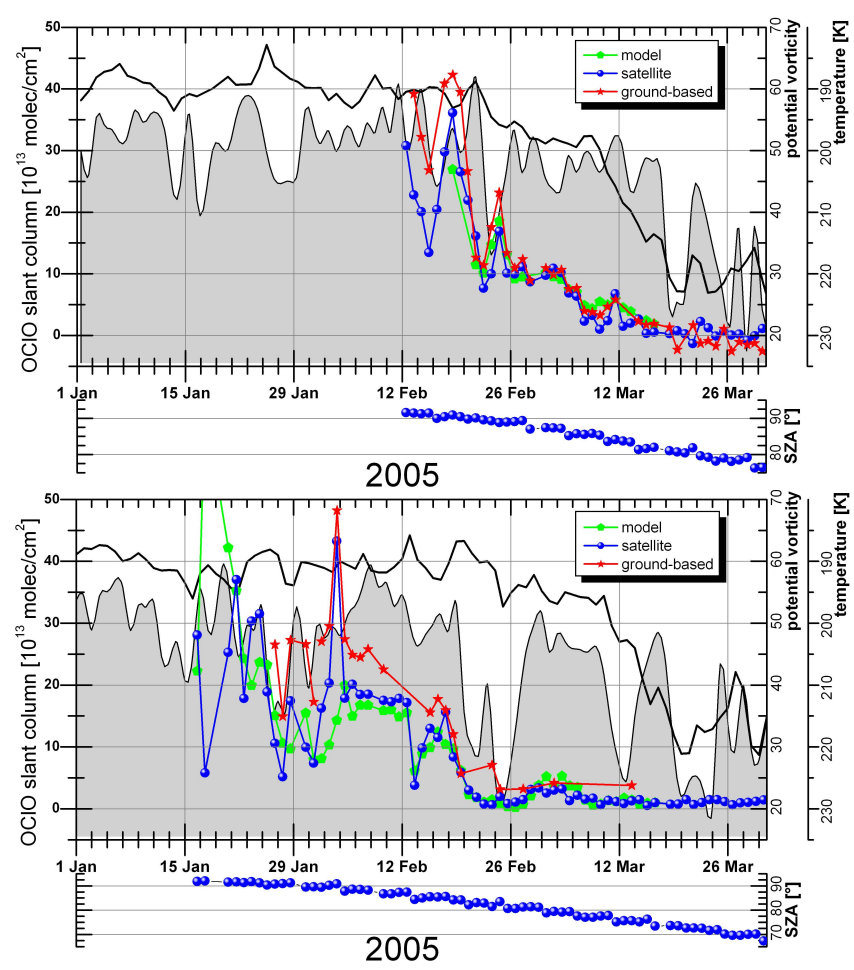

Fig. 4. Top: $\mathrm{OClO}$ slant columns over $\mathrm{Ny}$-Ålesund $\left(79^{\circ} \mathrm{N}, 12^{\circ} \mathrm{E}\right)$ in spring 2005 (axis on the left): Model data in green, satellite in blue and ground-based data in red. The ground-based data was sampled at the time of ENVISAT overpass. Also shown are potential vorticity (shaded area; axis on the right) and temperature (black line; axis on the right) at the $475 \mathrm{~K}$ isentropic surface. Bottom as top panel but for Summit, Greenland $\left(73^{\circ} \mathrm{N}, 38^{\circ} \mathrm{W}\right)$.

ground-based and satellite-based measurements probe the atmosphere several hundred kilometres away from the ground station but also not necessarily the same air mass. The exact location of the probed air depends on the position of the sun: In polar spring, the sun is always located towards the south resulting in a shift of the measurement volume into this direction. In addition, as the SCIAMACHY data is averaged within a radius of $200 \mathrm{~km}$ around the ground station and as there is a lack of measurements towards the polar night, i.e. the north, the majority of the measurements within this circle is shifted southward to smaller SZAs for days early in the year leading to a low bias in the data. An opposite effect can be observed for the ground-based data: The averaging over a $2^{\circ}$ range of SZAs results in a bias of the presented data to higher SZAs. In Ny-Ålesund, SZAs of $90^{\circ}$ and smaller are only reached from 18 February onwards, but the time series already starts on 13 February indicating that the SZA for these days is rather at the upper limit of the accepted range given by the SCIAMACHY measurement and hence biased to higher OClO. In contrast, it should be noted that although the radiative transfer model simulations consider the photochemical enhancement, the 1-D model cannot reproduce possible horizontal gradients along the light path which can result from varying chlorine activation or different air mass origins as described above. Following these initial two weeks of measurements, the agreement between the three data sets is very good in $\mathrm{Ny}$-Ålesund including the time period from about 16 March onwards when all three data sets agree on that there is no more $\mathrm{OClO}$ at the small SZAs of the SCIAMACHY overpass.

Over Summit, the agreement is only fair and variable. The ground-based measurements are up to $50 \%$ larger than the SCIAMACHY data whereas SCIAMACHY columns agree rather well with the modelled $\mathrm{OClO}$ amounts, although the large peak on 3 February is missed. On the other hand, to the end of the chlorine activation the qualitative agreement between model and satellite is better despite the fact that measurements are already close to the detection limit: Note the slight enhancement in $\mathrm{OClO}$ in the beginning of March. Also the decrease of $\mathrm{OClO}$ on 13 February is captured by the model but unfortunately missed by the ground-based measurement due to some equipment problems on these days.

\section{OClO over Bremen}

When the polar vortex becomes deformed and elongated it is possible that chlorine-activated air masses are transported to mid-latitudes. This provides an opportunity to detect $\mathrm{OClO}$ above Bremen as well. In Fig. 5, the ground-based and modelled data presented at $90^{\circ} \mathrm{SZA}$ are compared, including the SCIAMACHY data which was taken at much smaller SZAs and the corresponding modelled data at the time of over-flight. As the OClO signal is small under these conditions, the SCIAMACHY data had to be normalised by subtraction of measurements over the Pacific to remove small instrumental drifts. Several episodes with enhanced OClO are apparent in the data sets and good agreement is found between measurements and model results with differences around $1 \times 10^{13}$ molecules $\mathrm{cm}^{-2}$ or less.

It is interesting to note that despite the relatively high sun, SCIAMACHY detects enhanced $\mathrm{OClO}$ over Bremen during vortex excursions at SZAs as small as $65^{\circ}$. This illustrates the low detection limit of the measurements in spite of the offset problems which necessitate normalisation of the data. Unfortunately, the ground-based instrument in Bremen is not sensitive enough to detect these low amounts of $\mathrm{OClO}$ present at these small SZAs, but modelled OClO columns reproduce the observations from satellite. This is confirmation for the ability of the model to accurately reproduce $\mathrm{OClO}$ columns at high sun.

\section{SZA dependence of $\mathrm{OCIO}$}

For the SCIAMACHY validation, only the OClO data at the time of the satellite overpass was used and good agreement between model and measurements was found (within $\sim 4 \times 10^{13}$ molecules $\mathrm{cm}^{-2}$ at $\mathrm{Ny}$-Ålesund, $\sim 6 \times 10^{13}$ 


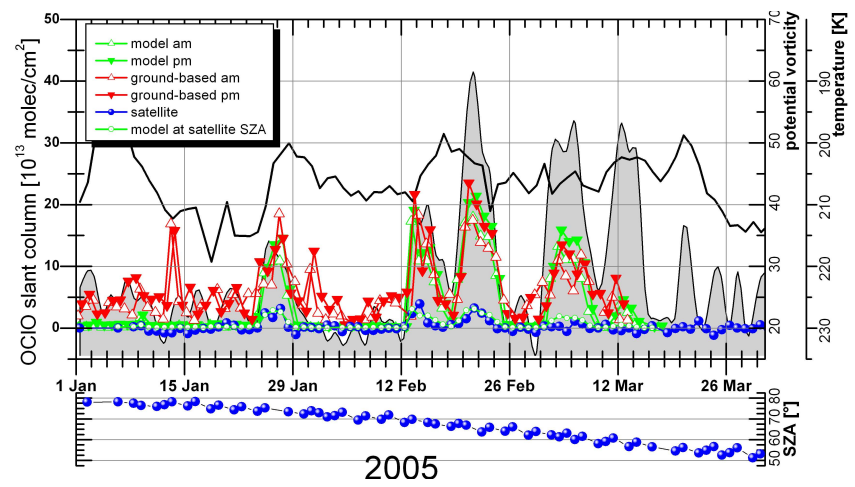

Fig. 5. OClO over Bremen $\left(53^{\circ} \mathrm{N}, 9^{\circ} \mathrm{E}\right.$; axis on the left): Model (green triangles) and ground-based data (red triangles) at $90^{\circ} \mathrm{SZA}$ and satellite (blue dots) at the SZA given below as well as model at the SCIAMACHY SZA (green circles), potential vorticity (shaded area) and temperature (black line) at the $475 \mathrm{~K}$ isentropic surface.

molecules $\mathrm{cm}^{-2}$ at Summit, and $\sim 1 \times 10^{13}$ molecules $\mathrm{cm}^{-2}$ at Bremen for SZAs $<90^{\circ}$ and for chlorine activated air masses only). However, it is also interesting and conventional to investigate the agreement between model and ground-based measurements at different SZAs.

In $2005 \mathrm{Ny}$-Ålesund was positioned well inside the vortex until 18 March. After this day the potential vorticity significantly decreased. Fig. 6 shows the ground-based and modelled OClO slant columns for different SZAs. There seems to be a positive offset of $4 \times 10^{13}$ molecules $\mathrm{cm}^{-2}$ in the measurements after the potential vorticity dropped. This could either be caused by some remaining chlorine activation or by a known problem for the OClO retrievals with the DOAS method: The proof of zero OClO is very difficult, and often a small positive offset is found even in situations where no chlorine activation is expected. This can also be observed in the data from the measurements in Bremen (Fig. 5) and previous works suggest a small positive offset as well (e.g. Fig. 6 in Aliwell et al. (1997) where the majority of data points is above 0; and Fig. 10 in Frieß et al. (2005) where OClO at Neymayer station is clearly above 0 in February and March). Whether or not this offset is also present in measurements with high OClO columns is not entirely clear; judging from the behaviour of OClO columns with SZA this appears not to be the case.

The general evolution of the chlorine activation, as well as the AM/PM-variation, is captured correctly by the model. In both data sets individual events like the peak on 24 February are also picked up. However, the model generally underestimates the OClO columns until 11March. This effect increases towards larger SZA but also with increasing chlorine activation. This is illustrated in Fig. 7, top panel for the time series including data from 24 February until 8 March as given in Fig. 6. On average, over the time period of strong chlorine activation until 8 March, the measurements exceed the model columns by $(5 \pm 12) \%$ at $88^{\circ} \mathrm{SZA},(22 \pm 7) \%$ at $90^{\circ}$

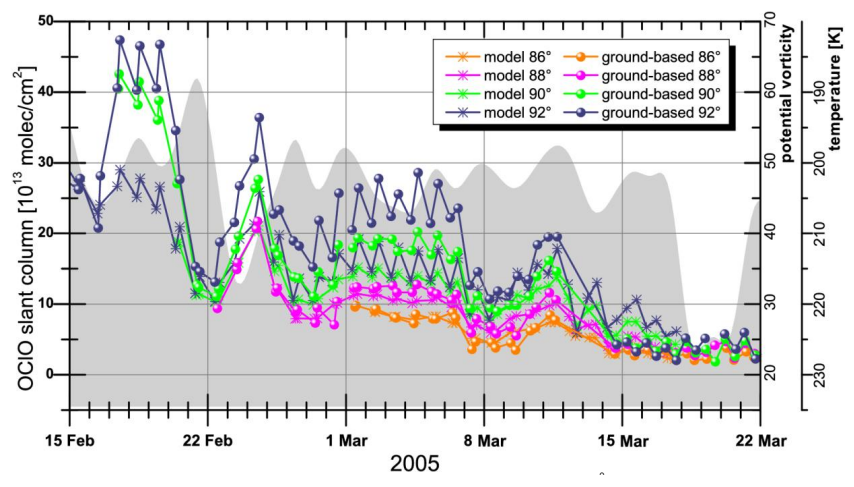

Fig. 6. Model (asterisks) and measurements (dots) of OClO at NyÅlesund $\left(79^{\circ} \mathrm{N}, 12^{\circ} \mathrm{E}\right)$ at four different SZAs (see box embedded in figure; axis on the left). Potential vorticity (shaded area) and temperature (black line) at the $475 \mathrm{~K}$ isentropic surface are also shown. Note that the zigzag pattern in the curves for high SZAs is caused by the diurnal variation of $\mathrm{OClO}$ with higher concentrations in the afternoon.

and $(26 \pm 15) \%$ at $92^{\circ}$ SZA. The uncertainties stated here are the standard deviations of the averaging over all days. However, the differences to the measurements depend on the measurement error as well. As stated above, the $2 \sigma$ measurement uncertainty is about $10 \%$ at $90^{\circ} \mathrm{SZA}$. The discrepancies between model and measurements are interpreted as indicating missing chemistry in the model, either related to photochemistry at low sun or to the formation of $\mathrm{OClO}$, which seems to be underestimated. The next section will investigate these model and measurement differences by examining the sensitivity of the results towards changes in certain model parameters.

It is also interesting to note that after 14 March, the model overestimates the measured OClO columns at large SZA over Ny-Ålesund. At this time, potential vorticity is still high, temperature is increasing and measurements show little OClO. The model overestimation could indicate that the parameterisation of chlorine activation in the SLIMCAT model is producing too strong chlorine activation at this time of the year.

\section{Model studies}

The box model simulations as well as the initialisation of it, presented in Sects. 3 to 5, were performed using the JPL 2002 (Sander et al., 2003) recommendations for the kinetic and photochemical parameters including the reaction of $\mathrm{BrONO}_{2}$ with $\mathrm{O}\left({ }^{3} \mathrm{P}\right)$ (Soller et al., 2001).

Uncertainties in chemistry models originate from the limited accuracy of our knowledge of: 

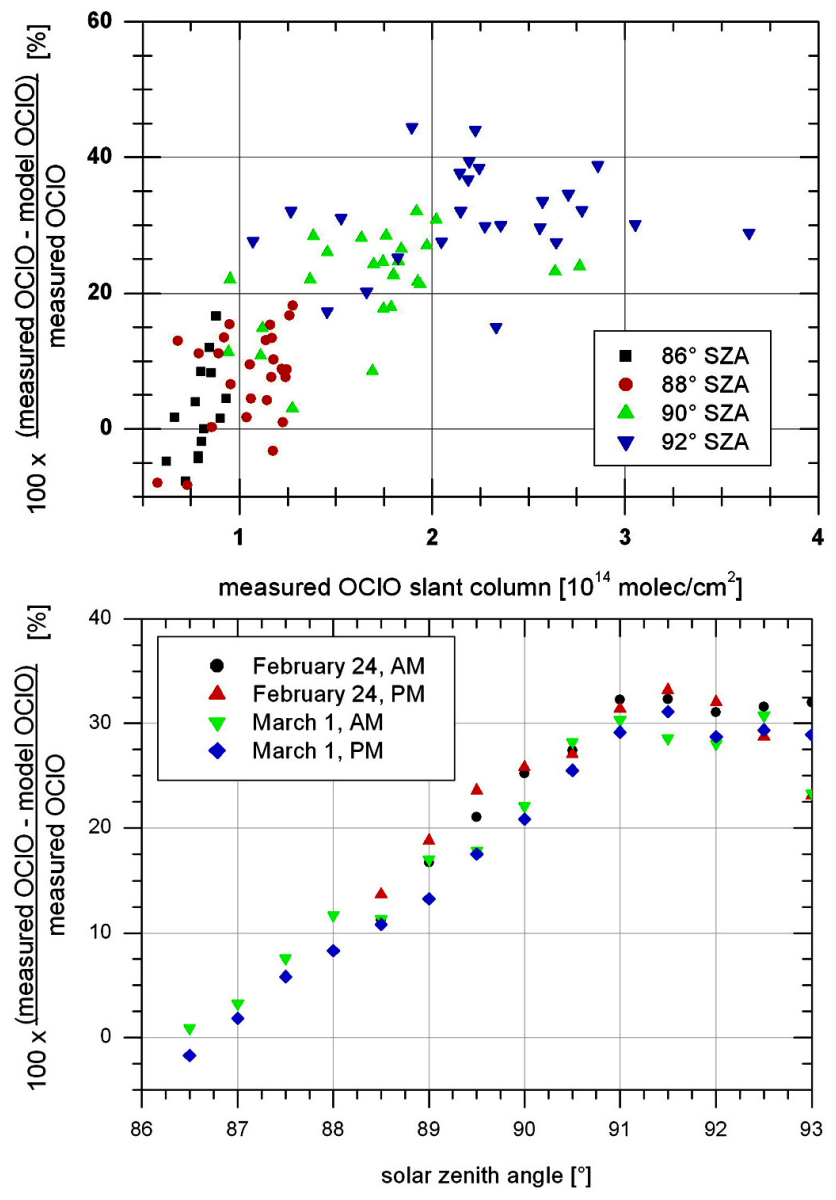

Fig. 7. The relative differences between modelled OClO columns and ground-based data for $\mathrm{Ny}$-Ålesund as a function of $\mathrm{OClO}$ (top) and SZA (bottom). Top: all data from 24 February until 8 March as given in Fig. 6 colour-coded for the four different solar zenith angle bins. Bottom: differences for two selected days as stated in the embedded box. The relative differences between modelled and measured $\mathrm{OClO}$ increase with chlorine activation as well as with SZA.

- the involved rate and equilibrium constants

- the absorption cross sections and quantum yields

- the photolysis frequencies of molecules

- the initialisation amount of trace species in the model

- the meteorology

Recently, several sensitivity studies of stratospheric chlorine chemistry suggested the need for adjusting some of the reaction rates as well as the absorption cross sections and consequently the photolysis rates of certain gases. These will be discussed in the following sections. The JPL recommendations have partly been updated (Sander et al., 2006, in future referred to as JPL 2006). Here, sensitivity tests are performed for the stacked box model simulations only and not for the simulation of the radiative transfer since good agreement was found for the simulations of $\mathrm{NO}_{2}$ slant columns (see Fig. 3). Several scenarios will be investigated. The focus is on 24 February in Ny-Ålesund. At $90^{\circ}$ SZA, the measurements exceed the modelled columns by about $26 \%$ on this day. The relative differences are shown to increase with increasing SZA (see Fig. 7, bottom panel and Fig. 8) and as described above are in general on average $22 \pm 7 \%$ at $90^{\circ}$ SZA showing that 24 February is a typical day.

\subsection{ClO-dimer cycle chemistry}

Comparisons of $\mathrm{OClO}$ measurements with model results are rather sparse (e.g. Butz et al., 2007; Fussen et al., 2006). Studies mainly concentrate on the simulation of measured $\mathrm{ClO}$ (e.g. Schofield et al., 2008), sometimes in combination with $\mathrm{Cl}_{2} \mathrm{O}_{2}$ measurements (e.g. von Hobe et al., 2005) testing the $\mathrm{ClO}$-dimer cycle chemistry. In general, it has been found that modelled chlorine monoxide is too low (e.g. Pierson et al., 1999; Solomon et al., 2000). Alongside the ClO$\mathrm{BrO}$ catalytic cycle, the $\mathrm{ClO}$-dimer cycle is a very efficient ozone depleting mechanism which is initiated by the $\mathrm{ClO}$ self-reaction. The main product has been shown to be in the form of chlorine peroxide $\mathrm{ClOOCl}$, which is the most stable one of the three possible isomers of the molecule $\mathrm{Cl}_{2} \mathrm{O}_{2}$. In future, $\mathrm{Cl}_{2} \mathrm{O}_{2}$ refers to $\mathrm{ClOOCl}$ unless stated otherwise. The ClO-dimer $\mathrm{Cl}_{2} \mathrm{O}_{2}$ is thermally decomposed in the presence of a third body $M$ :

$\mathrm{ClO}+\mathrm{ClO} \stackrel{M}{\rightleftarrows} \mathrm{Cl}_{2} \mathrm{O}_{2}$

or removed by photolysis:

$\mathrm{Cl}_{2} \mathrm{O}_{2}+h v \rightarrow \mathrm{Cl}+\mathrm{ClOO}$.

To increase the $\mathrm{ClO}$ and hence the $\mathrm{OClO}$ concentrations, the partitioning within the active chlorine family $\mathrm{ClO}_{x}$ (i.e. $\mathrm{ClO}+\mathrm{Cl}_{2} \mathrm{O}_{2}$ ) has to be shifted in favour of the $\mathrm{ClO}$. This can be achieved in three ways: Either by (a) increasing the photolysis rate or by (b) speeding up the thermal decomposition of $\mathrm{Cl}_{2} \mathrm{O}_{2}$ or by (c) decreasing the forward rate constant of Reaction (R2). These three scenarios will be discussed in more details in the following:

a. The JPL 2002/06 recommendations for the $\mathrm{ClOOCl}$ absorption cross section are an average of several values (Cox and Hayman, 1988; Burkholder et al., 1990; Permien et al., 1988; DeMore and Tschuikow-Roux, 1990). Some studies (Huder and DeMore, 1995; Pope et al., 2007) obtain significantly lower values in the tail region (see Fig. 5 in von Hobe et al., 2007) and overall, the spectra disagree by a factor of up to 20 . The recent study by Chen et al. (2009) confirmed the absorption cross section as obtained by Burkholder at al. (1990) at $351 \mathrm{~nm}$. Here, the extremes are tested: The Pope et al. (2007) cross section is the smallest available and the 
Burkholder et al. (1990) absorption cross section represents the upper limit of the set. Both have been extended to longer wavelengths by a log-linear extrapolation. The impact of using the different absorption cross sections for $\mathrm{Cl}_{2} \mathrm{O}_{2}$ in modelled $\mathrm{OClO}$ slant columns are large (see Fig. 8): up to $11 \%$ at $90^{\circ}$ SZA for the Burkholder et al. (1990) cross section and up to $-33 \%$ for the Pope et al. (2007) values. However, the change in absorption cross section causes simply an offset relative to the original model and does not explain the diurnal behaviour of the OClO. Table 1 shows the differences at $90^{\circ} \mathrm{SZA}$ also for 4 March. On this day, the $\mathrm{OClO}$ measurements at $90^{\circ} \mathrm{SZA}$ are too high by about $30 \%$ and this day is hence at the upper limit of the variations for the differences. However, the changes caused by changing the $\mathrm{Cl}_{2} \mathrm{O}_{2}$ absorption cross section lead to similar values as for 24 February, i.e. $12 \%$ and $-36 \%$.

b. During the daytime, at smaller SZA, photolysis dominates over the thermal decomposition of $\mathrm{Cl}_{2} \mathrm{O}_{2}$. However, with increasing SZAs, the thermal decomposition becomes more important. Several laboratory studies determining the equilibrium constant between $\mathrm{ClO}$ and $\mathrm{Cl}_{2} \mathrm{O}_{2}$ are available (Basco and Hunt, 1979; Cox and Hayman, 1988; Horowitz et al., 1994; Nickolaisen et al., 1994; Plenge et al., 2005; Bröske and Zabel, 2006). The JPL 2002/2006 recommendations are an average of Cox and Hayman (1988) and Nickolaisen et al. (1994), which were then extrapolated to the temperatures prevailing in the atmosphere. The recent photo-ionisation mass spectroscopy study by Plenge et al. (2005) suggests that the $\mathrm{ClOOCl}$ is by a factor of 0.3 less stable than previously assumed. This observation is confirmed at atmospheric temperatures by several studies based on air-borne in-situ measurements (Brune et al., 1991; Pierson et al., 1999; Avallone and Toohey, 2001; Stimpfle et al., 2004; von Hobe et al., 2005) and nighttime Odin satellite/ Osiris measurements (Berthet et al., 2005). By changing the equilibrium constant to the most recent value obtained by Bröske and Zabel (2006), a maximum increase in $\mathrm{OClO}$ of $3 \%$ at $90^{\circ} \mathrm{SZA}$ is achieved. As expected, the difference increases towards larger SZAs.

c. Another way to shift the partitioning within the $\mathrm{Cl}_{y}$ family in favour of $\mathrm{ClO}$ in the model simulations is achieved by decreasing the forward rate constant for the threebody formation of $\mathrm{Cl}_{2} \mathrm{O}_{2}$. JPL 2006 presents an average of Bloss et al. (2001), Nickolaisen et al. (1994), and Trolier et al. (1990). The more recent study by Boakes et al. (2005) rather increased the rate for this reaction decreasing the $\mathrm{OClO}$ by $6 \%$. However, adjusting the rate constant to the lower limit of the JPL recommendations increases the $\mathrm{OClO}$ column by $5 \%$ at $90^{\circ} \mathrm{SZA}$ and yields similar values to using Nickolaisen et al. (1994) alone.
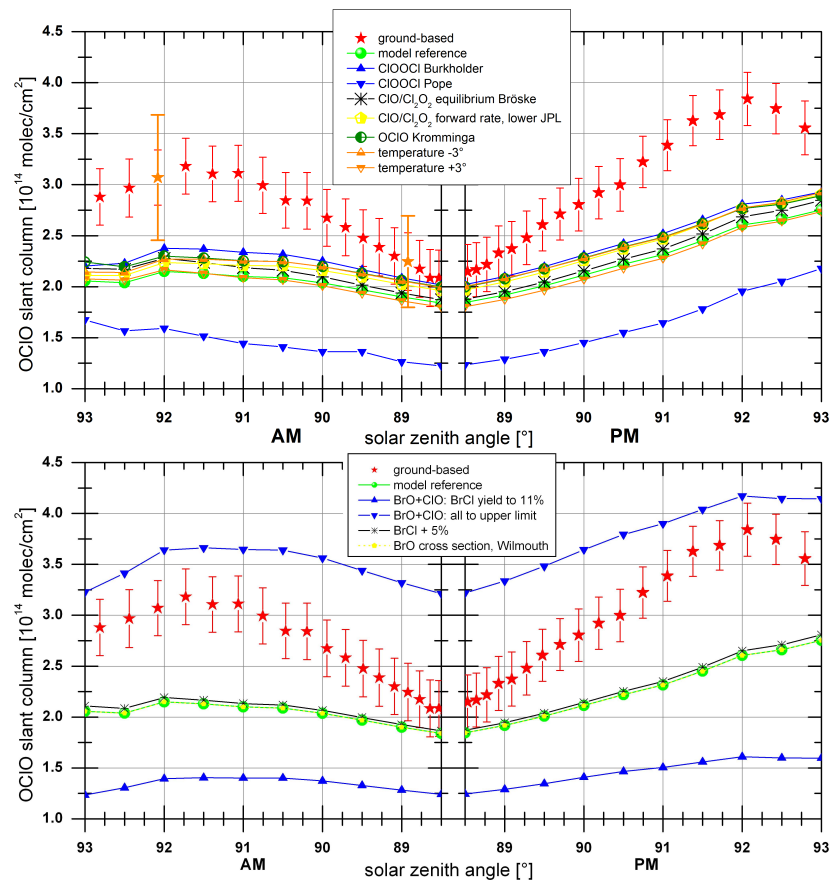

Fig. 8. Sensitivity Studies: measurements and model calculations of $\mathrm{OClO}$ slant columns at $\mathrm{Ny}$-Ålesund for 24 February. The error bars represent the $2 \sigma$ error of the measurements. Exemplarily, two error bars have been added to the top panel indicating the overall measurement uncertainty of $20 \%$. Sensitivity studies have been undertaken by changing the mechanism. The different scenarios are indicated in the box embedded in the figure and are explained in Sect. 6.

Schofield et al. (2008) retrieved a possible range for the combinations of the three model parameters from airborne measurements of $\mathrm{ClO}$ and they propose using a decreased forward rate constant for the $\mathrm{Cl}_{2} \mathrm{O}_{2}$ formation in combination with a smaller equilibrium constant in comparison to the JPL recommendations. Von Hobe et al. (2007) also reviewed the available laboratory references as well as rate theory calculations for the equilibrium constant between $\mathrm{ClO}$ and $\mathrm{Cl}_{2} \mathrm{O}_{2}$. They concluded that the best overall consistency with atmospheric observations as well as rate theory calculations can be found for the combination of the photolysis rates based on the $\mathrm{Cl}_{2} \mathrm{O}_{2}$ absorption cross section in the range of Burkholder et al. (1990) and JPL 2006, the equilibrium constant by Plenge et al. (2005), and the $\mathrm{Cl}_{2} \mathrm{O}_{2}$ formation rate constant by Nickolaisen et al. (1994). Although OClO columns are enhanced by up to $20 \%$, this is still not sufficient to explain the ground observations of OClO, reported in this study.

\subsection{BrO-ClO cycle chemistry}

As the amount of $\mathrm{BrO}$ determines how much $\mathrm{OClO}$ is produced (Schiller and Wahner, 1996), the implementation of the correct bromine load of the atmosphere is a crucial parameter for accurate modelling of the chlorine chemistry. 
Table 1. Summary of the sensitivity studies of the box model in comparison to the JPL 2002 simulation at a SZA of $90^{\circ}$. Texts in bold characters represent scenarios visualised in Fig. 8. More details can be found in the Sect. 6.

\begin{tabular}{|c|c|c|c|c|c|}
\hline \multirow[t]{3}{*}{ Parameter } & \multirow[t]{3}{*}{ Study } & \multicolumn{4}{|c|}{$\begin{array}{l}\text { Differences in } \mathrm{OClO} \text { to the reference } \\
\text { scenario at } 90^{\circ} \mathrm{SZA}\end{array}$} \\
\hline & & \multicolumn{2}{|c|}{24 February 2005} & \multicolumn{2}{|c|}{4 March 2005} \\
\hline & & $\mathrm{AM}$ & $\mathrm{PM}$ & AM & PM \\
\hline \multirow[t]{2}{*}{$\mathrm{ClOOCl}$ absorption cross section } & Burkholder et al. (1990) & $+11 \%$ & $+9 \%$ & $+12 \%$ & $+9 \%$ \\
\hline & Pope et al. (2007) & $-33 \%$ & $-31 \%$ & $-36 \%$ & $-31 \%$ \\
\hline $\mathrm{ClO} / \mathrm{Cl}_{2} \mathrm{O}_{2}$ equilibrium constant & Bröske and Zabel (2006) & $+3 \%$ & $+2 \%$ & $+3 \%$ & $+1 \%$ \\
\hline \multirow[t]{2}{*}{$\mathrm{ClO} / \mathrm{Cl}_{2} \mathrm{O}_{2}$ forward rate constant } & lower JPL limit/ & $+5 \%$ & $+5 \%$ & $+5 \%$ & $+5 \%$ \\
\hline & Boakes et al. (2005) & $-6 \%$ & $-6 \%$ & $-6 \%$ & $-6 \%$ \\
\hline Combination according to von & Burkholder et al. (1990) & & & & \\
\hline Hobe et al. (2007) & + Plenge et al. (2005) & $+19 \%$ & $+17 \%$ & $+20 \%$ & $+15 \%$ \\
\hline & + Nickolaisen et al. (1994) & & & & \\
\hline \multirow[t]{2}{*}{$\mathrm{Br}_{\mathrm{y}}$ initialisation } & $+3 \mathrm{ppt}$ & $+14 \%$ & $+14 \%$ & $+14 \%$ & $+14 \%$ \\
\hline & $-3 \mathrm{ppt}$ & $-14 \%$ & $-14 \%$ & $-14 \%$ & $-14 \%$ \\
\hline $\mathrm{BrO}$ cross section & Wilmouth et al. (1999) & $<<1 \%$ & $<<1 \%$ & $<<1 \%$ & $<<1 \%$ \\
\hline \multirow[t]{2}{*}{$\mathrm{BrO}+\mathrm{ClO}$ rate constants } & $\mathrm{BrCl}$ yield to $11 \%$ & $-33 \%$ & $-33 \%$ & $-29 \%$ & $-30 \%$ \\
\hline & all react. to upper limit & $+75 \%$ & $+72 \%$ & $+84 \%$ & $+79 \%$ \\
\hline $\mathrm{BrCl}$ absorption cross section & $+5 \%$ & $+1 \%$ & $+1 \%$ & $+1 \%$ & $+1 \%$ \\
\hline OClO absorption cross section & Kromminga et al. (2003) & $+8 \%$ & $+8 \%$ & $+8 \%$ & $+8 \%$ \\
\hline Temperature initialisation & $-3 \mathbf{K}$ & $+8 \%$ & $+8 \%$ & $+9 \%$ & $+9 \%$ \\
\hline
\end{tabular}

Generally, the inorganic bromine loading is believed to originate from a combination of long-lived bromine species

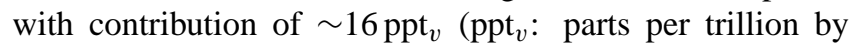
volume hereafter referred to as pt) and very short-lived bromine source gases of 3 to $8 \mathrm{ppt}$ (WMO, 2007). In the model, the overall $\mathrm{Br}_{\mathrm{y}}\left(=\mathrm{Br}+\mathrm{BrO}+\mathrm{BrONO}_{2}+\mathrm{HOBr}+\mathrm{BrCl}\right.$ $+\mathrm{HBr}$ ) volume mixing ratio is $21 \mathrm{ppt}$ which is achieved by scaling methyl bromide $\mathrm{CH}_{3} \mathrm{Br}$ to represent all bromine sources. This can underestimate the bromine load in the lower stratosphere (Hendrick et al., 2007; Theys et al., 2007; Schofield et al., 2006; Feng et al., 2007b). In order to test the effects towards the $\mathrm{Br}_{\mathrm{y}}$ initialisation, the profiles of the individual bromine species are scaled to yield a maximum $\mathrm{Br}_{\mathrm{y}}$ loading of $24 \mathrm{ppt}$ or $18 \mathrm{ppt}$. The difference on the $\mathrm{OClO}$ columns is symmetrical around the reference simulation with $14 \%$ at $90^{\circ}$ and it shows only a slight SZA dependence. This is still far off the required increase of $\mathrm{OClO}$ by $\sim 30 \%$.

The JPL 2006 recommendations for the $\mathrm{BrO}$ cross section were updated from the one reported by Wahner et al. (1987) to the high-resolution data set by Wilmouth et al. (1999) resulting in negligible effects of less than $1 \%$ in the OClO concentration. Bromine chloride $\mathrm{BrCl}$ is the product in one of the three channels of the $\mathrm{BrO}+\mathrm{ClO}$-reaction. It is the main inorganic bromine species during the night in periods of chlorine activation (Sinnhuber et al., 2002). On the basis of a night-time OClO profile measurement, Canty et al. (2005) suggest an increase in the $\mathrm{BrCl}$ yield from $7 \%$ to $11 \%$ is required. This value is consistent with the error bars of $63 \%$ of the rate constant at $195 \mathrm{~K}$ given by JPL 2002/2006. Atkinson et al. (2000) found a constant partitioning of $8 \%$ for this yield over a wide temperature range motivating Sinnhuber et al. (2002) to increase the rate constants of all three branches. As expected, changes in the rates of the directly involved reactions lead to the most dramatic effects of up to $84 \%$ and $-33 \%$ for increasing all or just one rate constant, respectively. However the increase and decrease in the OClO column densities stay constant over a SZA range of up to about $91^{\circ}$ resulting in much poorer agreement between model simulation and the measurements at local noon.

Increasing the photolysis rate of $\mathrm{BrCl}$ will shift the partitioning of bromine to active forms such as $\mathrm{BrO}$ during daytime but would also cause a faster increase of $\mathrm{BrO}$ in the morning. The model takes into account the temperature dependence of the $\mathrm{BrCl}$ absorption cross section as suggested by Maric et al. (1994). Tellinghuisen (2003) reports the largest of the available cross sections with a peak height 
exceeding Maric et al. (1994) by about $2.5 \%$ around $375 \mathrm{~nm}$ whereas the cross section by Hubinger and Nee (1995) is about $3.5 \%$ smaller in this wavelength region. Since the absorption cross sections exhibit a rather smooth distribution with wavelength, a simple scaling by $5 \%$ seems to be appropriate in order to simulate larger cross section. However, this increase changes the $\mathrm{OClO}$ column densities by only $1 \%$.

\subsection{Further tests of the modelled OClO sensitivity}

The absorption cross sections for $\mathrm{OClO}$ at a temperature of $204 \mathrm{~K}$, recommended by JPL 2002/06, are taken from Wahner et al. (1987). The DOAS fits of the measurements presented here are performed applying the cross sections by Kromminga et al. (2003) at 213 K. Kromminga et al. (2003) report band peaks about 8\% smaller than Wahner et al. (1987) leading to a constant offset in the slant column densities for $\mathrm{OClO}$ when applied in the modelling.

An accurate knowledge of the temperature in the model simulations is crucial since it determines whether chlorine will be activated or not. It is therefore possible that the temperature of an air mass at a higher spatial resolution might locally drop below the threshold for the formation of PSCs. Such effects are missed by the coarser vertical resolution of the model profile. In order to test the sensitivity of the simulations towards the temperature, a constant offset of $3 \mathrm{~K}$ has been subtracted. Decreasing the temperature, increases the vertical extent of the layer where chlorine activation is possible leading to higher concentrations of $\mathrm{OClO}$ of up to $9 \%$ at $90^{\circ} \mathrm{SZA}$.

Changes in the ground albedo in the model also have minor impacts of only about $2 \%$. As expected, the photolysis of OClO increases and consequently the concentration decreases towards larger albedo. However, this does not influence the SZA dependence of the $\mathrm{OClO}$ columns up to $91^{\circ}$ SZA. Furthermore, the photolysis rates of the box model calculated for OClO have been checked for consistency with SCIATRAN which includes full treatment of multiple scattering. The rates of the two models agree within 3\%. Also, reducing $\mathrm{NO}_{2}$ by $5 \%$ to impede the formation of the reservoir species chlorine nitrate yields a negligible effect.

\subsection{Discussion}

Table 1 summarises the contributions from the different scenarios to the OClO slant column densities at $90^{\circ} \mathrm{SZA}$ for the two days. The SZA dependence is presented only for 24 February in Fig. 8.

Adjusting the rate constant of the $\mathrm{BrO}+\mathrm{ClO}$-reaction has the largest influence on the $\mathrm{OClO}$ but introduces only an offset in the data. However, to reproduce the measurements a scaling is needed since the columns agree for low SZAs. In summary, none of the selected individual scenarios can fully explain the diurnal variation of the $\mathrm{OClO}$ observations or the absolute values at high SZAs. In the following, some pos- sible additional mechanisms are discussed although implementations in the model are beyond the scope of this study.

Laboratory measurements have shown that $\mathrm{OClO}$ evaporates from ice surfaces via heterogeneous reactions after being exposed to $\mathrm{ClO}$ radicals (McKeachie et al., 2004). It is suggested that this release is initiated by the formation of the $\mathrm{ClO} \cdot \mathrm{H}_{2} \mathrm{O}$ radical complex (Francisco and Sander, 1995; Galvez and Gomez, 2007). This could potentially increase the $\mathrm{OClO}$ columns.

Thornton et al. $(2003,2005)$ report measurements of $\mathrm{ClO}$ in the lowermost stratosphere at high latitude regions. They suggest heterogeneous chlorine activation on cold particulate surfaces as water-rich background aerosols containing sulphate and nitrate.

A chlorine species neglected in the model is $\mathrm{Cl}_{2}$. If significant amounts of active chlorine are stored in the form of this molecule, then this would give rise to an additional source of a SZA dependent formation of $\mathrm{ClO}$ and consequently $\mathrm{OClO}$ in the model. However, the explicit treatment of $\mathrm{Cl}_{2}$ would mainly increase the morning concentrations of $\mathrm{OClO}$ but leave the afternoon concentrations unchanged.

Possible roles of the two other $\mathrm{Cl}_{2} \mathrm{O}_{2}$ isomers chloryl chloride $\mathrm{ClClO}_{2}$ and chlorine chlorite $\mathrm{ClOClO}$ have been discussed in the literature before (Plenge et al., 2004; Bloss et al., 2001). Although these two species are much less stable than $\mathrm{ClOOCl}$, an additional source for OClO could arise from their photolysis.

\section{Summary}

The measurements, described in this study, are the first validation attempt of the OClO retrieved from SCIAMACHY observations made by comparison with ground-based remote sensing DOAS measurements. The agreement is fair to good depending on location and time of year, i.e. the local SZA. $\mathrm{OClO}$ could also be detected over the mid-latitude station Bremen during vortex excursions. It can be concluded that SCIAMACHY is delivering OClO slant column amounts with satisfactory accuracy and can thus be used to study the long-term evolution of stratospheric chlorine loading.

The SLIMCAT-initialised stacked box model simulations of OClO show good qualitative agreement with the day-today variations of the measurements and also good agreement at the time of satellite overpass. However, they underestimate the measured amount of $\mathrm{OClO}$, in particular at low sun and large chlorine activation. The absolute differences of the model to the measurements depend on the measurement error. The $2 \sigma$ measurement error is about $10 \%$ at $90^{\circ} \mathrm{SZA}$ and a conservative estimate for the overall uncertainty is $20 \%$. The differences between model and measurements are on average $(22 \pm 7) \%$ for $90^{\circ} \mathrm{SZA}$ and increase with SZA reaching values of up to $40 \%$. In general these differences are spread over a wide range depending on the particular day as well as time of day. The modelled amount of OClO can be 
varied by changing the chemistry in the model within the uncertainties of absorption cross-sections and rate coefficients. In addition to the overall underestimation, the model does not capture the magnitude of the $\mathrm{OClO}$ variation as a function of SZA. None of the sensitivity studies performed leads to a result which was in good agreement with the measurements with respect to the SZA dependence of the OClO column. From the model simulations of the $\mathrm{OClO}$ behaviour, it can be concluded that our knowledge of the physical and chemical processing within the vortex is not sufficient to explain the OClO behaviour adequately. This implies that the chlorine chemistry and its relevant mechanisms for the formation of OClO taking into account the range of the accuracies of the laboratory kinetics are not completely understood. Further research especially for the key rate constants of the chemical and photochemical reactions involving the chlorine oxides is needed.

Further validation of SCIAMACHY OClO in the Southern Hemisphere using ground-based measurements and comparisons with models will provide more information with respect to our understanding of the OClO sources and sinks and related halogen chemistry. A comparison of OClO retrieved with GOME-1 and the new GOME-2 data in the period of overlapping measurements would be valuable to produce consolidated data sets.

Acknowledgements. The setup of the BREDOM stations has been funded in parts by the German Federal Ministry of Education and Research (BMBF), the German Aerospace Agency (DLR), the European Union, the University of Bremen and the State of Bremen. The SCIAMACHY scientific support in Bremen has been funded by the DLR. The authors thank the staff of the Koldewey station in Ny-Ålesund and of the Summit station in Greenland for their support. SCIAMACHY spectra were provided by ESA through DFD/ DLR. Parts of this study were funded by the European Union through the GEOMON project and by ESA through the TASTE project.

Edited by: W. Lahoz

\section{References}

Aliwell, S. R., Jones, R. L., and Fish, D. J.: Mid-latitude observations of the seasonal variation of BrO.1, Zenith-sky measurements, Geophys. Res. Lett., 24, 1195-1198, 1997.

Aliwell, S. R., Van Roozendael, M., Johnston, P. V., Richter, A., Wagner, T., Arlander, D. W., Burrows, J. P., Fish, D. J., Jones, R. L., Tørnkvist, K. K., Lambert, J. C., Pfeilsticker, K., and Pundt, I.: Analysis for $\mathrm{BrO}$ in zenith-sky spectra: An intercomparison exercise for analysis improvement, J. Geophys. Res.-Atmos., 107(20), 4199, doi:10.1029/2001jd000329, 2002.

Atkinson, R., Baulch, D. L., Cox, R. A., Hampson, R. F., Kerr, J. A., Rossi, M. J., and Troe, J.: Evaluated kinetic and photochemical data for atmospheric chemistry: Supplement VIII, halogen species - IUPAC Subcommittee on Gas Kinetic Data Evaluation for Atmospheric Chemistry, J. Phys. Chem. Ref. Data, 29, 167$266,2000$.
Avallone, L. M. and Toohey, D. W.: Tests of halogen photochemistry using in situ measurements of $\mathrm{CIO}$ and $\mathrm{BrO}$ in the lower polar stratosphere, J. Geophys. Res.-Atmos., 106, 10411-10421, 2001.

Barret, B., Ricaud, P., Santee, M. L., Attie, J. L., Urban, J., Le Flochmoen, E., Berthet, G., Murtagh, D., Eriksson, P., Jones, A., de la Noe, J., Dupuy, E., Froidevaux, L., Livesey, N. J., Waters, J. W., and Filipiak, M. J.: Intercomparisons of trace gases profiles from the Odin/SMR and Aura/MLS limb sounders, J. Geophys. Res.-Atmos., 111(11), D21302, doi:10.1029/2006jd007305, 2006.

Basco, N. and Hunt, J. E.: Mutual Combination of ClO Radicals, Int. J. Chem. Kinet., 11, 649-664, 1979.

Berthet, G., Ricaud, P., Lefevre, F., Le Flochmoen, E., Urban, J., Barret, B., Lautie, N., Dupuy, E., De la Noe, J., and Murtagh, D.: Nighttime chlorine monoxide observations by the Odin satellite and implications for the $\mathrm{ClO} / \mathrm{Cl}_{2} \mathrm{O}_{2}$ equilibrium, Geophys. Res. Lett., 32(5), L11812, doi:10.1029/2005g1022649, 2005.

Bloss, W. J., Nickolaisen, S. L., Salawitch, R. J., Friedl, R. R., and Sander, S. P.: Kinetics of the $\mathrm{ClO}$ self-reaction and $210 \mathrm{~nm}$ absorption cross section of the $\mathrm{ClO}$ dimer, J. Phys. Chem. A, 105, 11226-11239, 2001.

Boakes, G., Mok, W. H. H., and Rowley, D. M.: Kinetic studies of the $\mathrm{ClO}$ plus $\mathrm{ClO}$ association reaction as a function of temperature and pressure, Phys. Chem. Chem. Phys., 7, 4102-4113, 2005.

Bovensmann, H., Burrows, J. P., Buchwitz, M., Frerick, J., Noel, S., Rozanov, V. V., Chance, K. V., and Goede, A. P. H.: SCIAMACHY: Mission objectives and measurement modes, J. Atmos. Sci., 56, 127-150, 1999.

Bröske, R. and Zabel, F.: Thermal decomposition of ClOOCl, J. Phys. Chem. A, 110, 3280-3288, 2006.

Brune, W. H. and Anderson, J. G.: In situ observations of midlatitude stratospheric $\mathrm{ClO}$ and BrO, Geophys. Res. Lett., 13, 13911394, 1986.

Brune, W. H., Anderson, J. G., Toohey, D. W., Fahey, D. W., Kawa, S. R., Jones, R. L., McKenna, D. S., and Poole, L. R.: The potential for ozone depletion in the Arctic polar stratosphere, Science, 252, 1260-1266, 1991.

Burkholder, J. B., Orlando, J. J., and Howard, C. J.: UltravioletAbsorption Cross-Section of $\mathrm{Cl}_{2} \mathrm{O}_{2}$ between 210 and $410 \mathrm{~nm}, \mathrm{~J}$. Phys. Chem., 94, 687-695, 1990.

Burrows, J. P., Holzle, E., Goede, A. P. H., Visser, H., and Fricke, W.: SCIAMACHY - Scanning Imaging Absorption Spectrometer for Atmospheric Chartography, Acta Astronaut., 35, 445451, 1995.

Burrows, J. P., Weber, M., Buchwitz, M., Rozanov, V., LadstatterWeissenmayer, A., Richter, A., DeBeek, R., Hoogen, R., Bramstedt, K., Eichmann, K. U., and Eisinger, M.: The global ozone monitoring experiment (GOME): Mission concept and first scientific results, J. Atmos. Sci., 56, 151-175, 1999.

Butz, A., Bösch, H., Camy-Peyret, C., Dorf, M., Engel, A., Payan, S., and Pfeilsticker, K.: Observational constraints on the kinetics of the $\mathrm{ClO}-\mathrm{BrO}$ and $\mathrm{ClO}-\mathrm{ClO}$ ozone loss cycles in the Arctic winter stratosphere, Geophys. Res. Lett., 34(5), L05801, doi:10.1029/2006g1028718, 2007.

Canty, T., Riviere, E. D., Salawitch, R. J., Berthet, G., Renard, J. B., Pfeilsticker, K., Dorf, M., Butz, A., Bosch, H., Stimpfle, R. M., Wilmouth, D. M., Richard, E. C., Fahey, D. W., Popp, P. J., 
Schoeberl, M. R., Lait, L. R., and Bui, T. P.: Nighttime OCIO in the winter Arctic vortex, J. Geophys. Res.-Atmos., 110, 1-13, 2005.

Chen, H. Y., Lien, C. Y., Lin, W. Y., Lee, Y. T., and Lin, J. J.: UV Absorption Cross Sections of $\mathrm{ClOOCl}$ Are Consistent with Ozone Degradation Models, Science, 324, 781-784, doi:10.1126/science.1171305, 2009.

Chipperfield, M. P.: Multiannual simulations with a threedimensional chemical transport model, J. Geophys. Res.-Atmos., 104, 1781-1805, 1999.

Chubachi, S.: Preliminary result of ozone observations at Syowa station from February 1982 to January 1983, Mem. Natl. Inst. Polar Res., 34, 13-19, 1984.

Cox, R. A. and Hayman, G. D.: The Stability and Photochemistry of Dimers of the ClO Radical and Implications for Antarctic Ozone Depletion, Nature, 332, 796-800, 1988.

DeMore, W. B. and Tschuikow-Roux, E.: Ultraviolet-Spectrum and Chemical-Reactivity of the ClO Dimer, J. Phys. Chem., 94, 5856-5860, 1990.

Farman, J. C., Gardiner, B. G., and Shanklin, J. D.: Large losses of total ozone in Antarctica reveal seasonal $\mathrm{ClO}_{\mathrm{X}} / \mathrm{NO}_{\mathrm{X}}$ interaction, Nature, 315, 207-210, 1985.

Feng, W., Chipperfield, M. P., Davies, S., von der Gathen, P., Kyro, E., Volk, C. M., Ulanovsky, A., and Belyaev, G.: Large chemical ozone loss in 2004/2005 Arctic winter/spring, Geophys. Res. Lett., 34(6), L09803, doi:10.1029/2006g1029098, 2007a.

Feng, W., Chipperfield, M. P., Dorf, M., Pfeilsticker, K., and Ricaud, P.: Mid-latitude ozone changes: studies with a 3-D CTM forced by ERA-40 analyses, Atmos. Chem. Phys., 7, 2357-2369, doi:10.5194/acp-7-2357-2007, 2007b.

Francisco, J. S. and Sander, S. P.: Existence of a chlorine oxide and water $\left(\mathrm{ClO} \cdot \mathrm{H}_{2} \mathrm{O}\right)$ radical complex, J. Am. Chem. Soc., 117, 9917-9918, 1995.

Friedl, R. R. and Sander, S. P.: Kinetics and Product Studies of the Reaction $\mathrm{ClO}+\mathrm{BrO}$ Using Discharge-Flow Mass-Spectrometry, J. Phys. Chem., 93, 4756-4764, 1989.

Frieß, U., Kreher, K., Johnston, P. V., and Platt, U.: Ground-based DOAS measurements of stratospheric trace gases at two Antarctic stations during the 2002 ozone hole period, J. Atmos. Sci., 62, 765-777, 2005.

Fussen, D., Vanhellemont, F., Dodion, J., Bingen, C., Mateshvili, N., Daerden, F., Fonteyn, D., Errera, Q., Chabrillat, S., Kyrola, E., Tamminen, J., Sofieva, V., Hauchecorne, A., Dalaudier, F., Bertaux, J. L., Renard, J. B., Fraisse, R., d'Andon, O. F., Barrot, G., Guirlet, M., Mangin, A., Fehr, T., Snoeij, P., and Saavedra, L.: A global OClO stratospheric layer discovered in GOMOS stellar occultation measurements, Geophys. Res. Lett., 33, L13815, doi:10.1029/2006GL026406, 2006.

Galvez, O. and Gomez, P. C.: An ab initio study on the structure and energetics of the $\mathrm{ClO}$ hydrates, Chem. Phys. Lett., 448, 16-23, doi:10.1016/j.cplett.2007.09.072, 2007.

Gil, M., Puentedura, O., Yela, M., Parrondo, C., Jadhav, D. B., and Thorkelsson, $\mathrm{B}$.: $\mathrm{OClO}, \mathrm{NO}_{2}$ and $\mathrm{O}_{3}$ total column observations over Iceland during the winter 1993/94, Geophys. Res. Lett., 23, 3337-3340, 1996.

Heckel, A., Richter, A., Tarsu, T., Wittrock, F., Hak, C., Pundt, I., Junkermann, W., and Burrows, J. P.: MAX-DOAS measurements of formaldehyde in the Po-Valley, Atmos. Chem. Phys., 5, 909 918, doi:10.5194/acp-5-909-2005, 2005.
Hendrick, F., Van Roozendael, M., Kylling, A., Petritoli, A., Rozanov, A., Sanghavi, S., Schofield, R., von Friedeburg, C., Wagner, T., Wittrock, F., Fonteyn, D., and De Maziére, M.: Intercomparison exercise between different radiative transfer models used for the interpretation of ground-based zenith-sky and multi-axis DOAS observations, Atmos. Chem. Phys., 6, 93-108, doi:10.5194/acp-6-93-2006, 2006.

Hendrick, F., Van Roozendael, M., Chipperfield, M. P., Dorf, M., Goutail, F., Yang, X., Fayt, C., Hermans, C., Pfeilsticker, K., Pommereau, J.-P., Pyle, J. A., Theys, N., and De Maziére, M.: Retrieval of stratospheric and tropospheric BrO profiles and columns using ground-based zenith-sky DOAS observations at Harestua, $60^{\circ} \mathrm{N}$, Atmos. Chem. Phys., 7, 4869-4885, doi:10.5194/acp-7-4869-2007, 2007.

Hermans, C., Vandaele, A. C., Carleer, M., Fally, S., Colin, R., Jenouvrier, A., Coquart, B., and Merienne, M. F.: Absorption cross-sections of atmospheric constituents: $\mathrm{NO}_{2}, \mathrm{O}_{2}$, and $\mathrm{H}_{2} \mathrm{O}$, Environ. Sci. Pollut. R. 6, 151-158, 1999.

Horowitz, A., Crowley, J. N., and Moortgat, G. K.: TemperatureDependence of the Product Branching Ratios of the ClO SelfReaction in Oxygen, J. Phys. Chem., 98, 11924-11930, 1994.

Hubinger, S. and Nee, J. B.: Absorption-Spectra of $\mathrm{Cl}_{2}, \mathrm{Br}_{2}$ and $\mathrm{BrCl}$ between $190 \mathrm{~nm}$ and $600 \mathrm{~nm}$, J. Photoch. Photobio. A, 86, 1-7, 1995.

Huder, K. J., and DeMore, W. B.: Absorption Cross-Sections of the ClO Dimer, J. Phys. Chem., 99, 3905-3908, 1995.

Krecl, P., Haley, C. S., Stegman, J., Brohede, S. M., and Berthet, G.: Retrieving the vertical distribution of stratospheric OClO from Odin/OSIRIS limb-scattered sunlight measurements, Atmos. Chem. Phys., 6, 1879-1894, doi:10.5194/acp-6-1879-2006, 2006.

Kreher, K., Keys, J. G., Johnston, P. V., Platt, U., and Liu, X.: Ground-based measurements of $\mathrm{OClO}$ and $\mathrm{HCl}$ in austral spring 1993 at Arrival Heights, Antarctica, Geophys. Res. Lett., 23, 1545-1548, 1996.

Kromminga, H., Orphal, J., Spietz, P., Voigt, S., and Burrows, J. P.: New measurements of $\mathrm{OClO}$ absorption cross-sections in the $325-435 \mathrm{~nm}$ region and their temperature dependence between 213 and 293 K, J. Photoch. Photobio. A, 157, 149-160, 2003.

Kühl, S.: Quantifying Stratospheric Chlorine Chemistry by the Satellite Spectrometers GOME and SCIAMACHY, Dr. rer nat, Institute of Environmental Physics, University of Heidelberg, Heidelberg, 2005.

Kühl, S., Dornbrack, A., Wilms Grabe, W., Sinnhuber, B. M., Platt, U., and Wagner, T.: Observational evidence of rapid chlorine activation by mountain waves above northern Scandinavia, J. Geophys. Res.-Atmos., 109, 1-18, 2004a.

Kühl, S., Wilms-Grabe, W., Beirle, S., Frankenberg, C., Grzegorski, M., Hollwedel, J., Khokhar, F., Kraus, S., Platt, U., Sanghavi, S., von Friedeburg, C., and Wagner, T.: Stratospheric chlorine activation in the Arctic winters 1995/1996-2001/2002 derived from GOME OClO measurements, Trace Constituents in the Troposphere and Lower Stratosphere, 34, 798-803, 2004b.

Kühl, S., Pukite, J., Deutschmann, T., Platt, U., and Wagner, T.: SCIAMACHY limb measurements of $\mathrm{NO}_{2}, \mathrm{BrO}$ and OClO, Retrieval of vertical profiles: Algorithm, first results, sensitivity and comparison studies, Adv. Space Res., 42, 1747-1764, doi:10.1016/j.asr.2007.10.022, 2008.

Lary, D. J.: Catalytic Destruction of Stratospheric Ozone, J. Geo- 
phys. Res., 102, 21515-21526, 1997.

Maric, D., Burrows, J. P., and Moortgat, G. K.: A Study of the UV-Visible Absorption-Spectra of $\mathrm{Br}_{2}$ and $\mathrm{BrCl}$, J. Photochem. Photobiol. A-Chem., 83, 179-192, 1994.

McElroy, M. B., Salawitch, R. J., Wofsy, S. C., and Logan, J. A.: Reduction of Antarctic ozone due to synergistic interactions of chlorine and bromine, Nature, 321, 759-762, 1986.

McKeachie, J. R., Appel, M. F., Kirchner, U., Schindler, R. N., and Benter, T.: Observation of a heterogeneous source of $\mathrm{OClO}$ from the reaction of $\mathrm{ClO}$ radicals on ice, J. Phys. Chem. B, 108, 16786-16797, 2004.

Nickolaisen, S. L., Friedl, R. R., and Sander, S. P.: Kinetics and Mechanism of the $\mathrm{ClO}+\mathrm{ClO}$ Reaction - Pressure and Temperature Dependences of the Bimolecular and Termolecular Channels and Thermal-Decomposition of Chlorine Peroxide, J. Phys. Chem., 98, 155-169, 1994.

Otten, C., Ferlemann, F., Platt, U., Wagner, T., and Pfeilsticker, K.: Groundbased DOAS UV/visible measurements at Kiruna (Sweden) during the SESAME winters 1993/1994 and 1994/1995, J. Atmos. Chem., 30, 141-162, 1998.

Permien, T., Vogt, R., and Schindler, R. N.: Mechanisms of Gas Phase-Liquid Phase Chemical Transformations, in: Air Pollution Report \#17, edited by: Cox, R. A., Environmental Research Program of the CEC, Brussels, 1988.

Perner, D., Roth, A., and Klüpfel, T.: Groundbased measurements of stratospheric $\mathrm{OClO}, \mathrm{NO}_{2}$, and $\mathrm{O}_{3}$ at Søndre Strømfjord in winter 1991/1992, Geophys. Res. Lett., 21, 1367-1370, 1994.

Pierson, J. M., McKinney, K. A., Toohey, D. W., Margitan, J., Schmidt, U., Engel, A., and Newman, P. A.: An investigation of $\mathrm{ClO}$ photochemistry in the chemically perturbed arctic vortex, J. Atmos. Chem., 32, 61-81, 1999.

Plenge, J., Flesch, R., Kühl, S., Vogel, B., Muller, R., Stroh, F., and Ruhl, E.: Ultraviolet photolysis of the CIO dimer, J. Phys. Chem. A, 108, 4859-4863, doi:10.1021/jp049690, 2004.

Plenge, J., Kühl, S., Vogel, B., Muller, R., Stroh, F., von Hobe, M., Flesch, R., and Ruhl, E.: Bond strength of chlorine peroxide, J. Phys. Chem. A, 109, 6730-6734, doi:10.1021/jp044142h, 2005.

Pommereau, J. P. and Piquard, J.: Ozone and nitrogen dioxide vertical distributions by UV-visible solar occultation from balloons, Geophys. Res. Lett., 21, 1227-1230, 1994.

Pope, F. D., Hansen, J. C., Bayes, K. D., Friedl, R. R., and Sander, S. P.: Ultraviolet absorption spectrum of chlorine peroxide, $\mathrm{ClOOCl}$, J. Phys. Chem. A, 111, 4322-4332, doi:10.1021/jp067660w, 2007.

Renard, J. B., Lefevre, F., Pirre, M., Robert, C., and Huguenin, D.: Verticle profile of night-time stratospheric OClO, J. Atmos. Chem., 26, 65-76, 1997.

Richter, A., Eisinger, M., Ladstätter-Weißenmayer, A., and Burrows, J. P.: DOAS Zenith sky observations: 2. Seasonal variation of BrO over Bremen ( $\left.53^{\circ} \mathrm{N}\right)$ 1994-1995, J. Atmos. Chem., 32, 83-99, 1999.

Richter, A., Wittrock, F., Weber, M., Beirle, S., Kühl, S., Platt, U., Wagner, T., Wilms-Grabe, W., and Burrows, J. P.: GOME observations of stratospheric trace gas distributions during the splitting vortex event in the Antarctic winter of 2002, Part I: Measurements, J. Atmos. Sci., 62, 778-785, 2005.

Riviere, E. D., Pirre, M., Berthet, G., Renard, J. B., Taupin, F. G., Huret, N., Chartier, M., Knudsen, B., and Lefevre, F.: On the interaction between nitrogen and halogen species in the Arctic polar vortex during THESEO and THESEO 2000, J. Geophys. Res.-Atmos., 108(D5), 8311, doi:10.1029/2002JD002087, 2003.

Rozanov, A., Rozanov, V., and Burrows, J. P.: A numerical radiative transfer model for a spherical planetary atmosphere: combined differential-integral approach involving the Picard iterative approximation, J. Quant. Spectros. Ra., 69, 491-512, 2001.

Rozanov, A., Rozanov, V., Buchwitz, M., Kokhanovsky, A., and Burrows, J. P.: SCIATRAN 2.0 - A new radiative transfer model for geophysical applications in the $175-2400 \mathrm{~nm}$ spectral region, Adv. Space Res., 36, 1015-1019, doi:10.1016/j.asr.2005.03.012, 2005.

Sander, S. P., Friedel, R. R., Golden, D. M., Kurylo, M. J., Huie, R. E., Orkin, V. L., Moortgat, G. K., Ravishankara, A. R., Kolb, C. E., Molina, M. J., and Finlayson-Pitts, B. J.: Chemical Kinetics and Photochemical Data for Use in Atmospheric Studies - Evaluation Number 14, Jet Propulsion Laboratory, California Institute of Technology, Pasadena, California, 2003.

Sander, S. P., Friedel, R. R., Golden, D. M., Kurylo, M. J., Moortgat, G. K., Keller-Rudek, H., Wine, P. H., Ravishankara, A. R., Kolb, C. E., Molina, M. J., Finlayson-Pitts, B. J., Huie, R. E., and Orkin, V. L.: Chemical Kinetics and Photochemical Data for Use in Atmospheric Studies - Evaluation Number 15, Jet Propulsion Laboratory, California Institute of Technology, Pasadena, California, 2006.

Sanders, R. W., Solomon, S., Smith, J. P., Perliski, L., Miller, H. L., Mount, G. H., Keys, J. G., and Schmeltekopf, A. L.: Visible and near-ultraviolet spectroscopy at McMurdo Station, Antarctica 9. Observations of OClO from April to October 1991, J. Geophy. Res., 98, 7219-7228, 1993.

Santee, M. L., MacKenzie, I. A., Manney, G. L., Chipperfield, M. P., Bernath, P. F., Walker, K. A., Boone, C. D., Froidevaux, L., Livesey, N. J., and Waters, J. W.: A study of stratospheric chlorine partitioning based on new satellite measurements and modeling, J. Geophys. Res.-Atmos., 113, 25, D12307, doi:10.1029/2007jd009057, 2008.

Schiller, C. and Wahner, A.: Comment on "Stratospheric OClO measurements as a poor quanitatative indicator of chlorine activation", Geophys. Res. Lett., 23, 1053-1054, 1996.

Schiller, C., Wahner, A., Platt, U., Dorn, H. P., Callies, J., and Ehhalt, D. H.: Near UV atmospheric absorption measurements of column abundances during Airborne Arctic Stratospheric Expedition, January-February 1989: 2. OClO observations, Geophys. Res. Lett., 17, 501-504, 1990.

Schofield, R., Johnston, P. V., Thomas, A., Kreher, K., Connor, B. J., Wood, S., Shooter, D., Chipperfield, M. P., Richter, A., von Glasow, R., and Rodgers, C. D.: Tropospheric and stratospheric BrO columns over Arrival Heights, Antarctica, 2002, J. Geophys. Res.-Atmos., 111, 14, D22310, doi:10.1029/2005jd007022, 2006.

Schofield, R., Frieler, K., Wohltmann, I., Rex, M., von Hobe, M., Stroh, F., Koch, G., Peter, T., Canty, T., Salawitch, R., and Volk, C. M.: Polar stratospheric chlorine kinetics from a self-match flight during SOLVE-II/EUPLEX, Geophys. Res. Lett., 35(6), L01807, doi:10.1029/2007g1031740, 2008.

Sinnhuber, B. M., Arlander, D. W., Bovensmann, H., Burrows, J. P., Chipperfield, M. P., Enell, C. F., Frieß, U., Hendrick, F., Johnston, P. V., Jones, R. L., Kreher, K., Mohamed-Tahrin, N., Muller, R., Pfeilsticker, K., Platt, U., Pommereau, J. P., Pundt, I., Richter, A., South, A. M., Tørnkvist, K. K., Van Roozendael, 
M., Wagner, T., and Wittrock, F.: Comparison of measurements and model calculations of stratospheric bromine monoxide, J. Geophys. Res.-Atmos., 107, 4398, doi:10.1029/2001JD000940, 2002.

Sinnhuber, B. M., Rozanov, A., Sheode, N., Afe, O. T., Richter, A., Sinnhuber, M., Wittrock, F., Burrows, J. P., Stiller, G. P., von Clarmann, T., and Linden, A.: Global observations of stratospheric bromine monoxide from SCIAMACHY, Geophys. Res. Lett., 32, L20810, doi:10.1029/2005GL023839, 2005.

Soller, R., Nicovich, J. M., and Wine, P. H.: Temperature-dependent rate coefficients for the reactions of $\mathrm{Br}\left({ }^{2} \mathrm{P}_{3 / 2}\right), \mathrm{Cl}\left({ }^{2} \mathrm{P}_{3 / 2}\right)$, and $\mathrm{O}\left({ }^{3} \mathrm{P}_{J}\right)$ with $\mathrm{BrONO}_{2}$, J. Phys. Chem. A, 105, 1416-1422, 2001.

Solomon, S., Mount, G. H., Sanders, R. W., and Schmeltekopf, A. L.: Visible Spectroscopy at McMurdo Station, Antarctica - 2. Observations of OClO, J. Geophys. Res., 92, 8329-8338, 1987a.

Solomon, S., Schmeltekopf, A. L., and Sanders, R. W.: On the Interpretation of Zenith Sky Absorption Measurements, J. Geophys. Res., 92, 8311-8319, 1987b.

Solomon, S., Mount, G. H., Sanders, R. W., Jakoubek, R. O., and Schmeltekopf, A. L.: Observations of the nighttime abundance of $\mathrm{OClO}$ in the winter stratosphere above Thule, Greenland, Science, 242, 550-555, 1988.

Solomon, P., Barrett, J., Connor, B., Zoonematkermani, S., Parrish, A., Lee, A., Pyle, J., and Chipperfield, M.: Seasonal observations of chlorine monoxide in the stratosphere over Antarctica during the 1996-1998 ozone holes and comparison with the SLIMCAT three-dimensional model, J. Geophys. Res.-Atmos., 105, 2897929001, 2000.

Stimpfle, R. M., Wilmouth, D. M., Salawitch, R. J., and Anderson, J. G.: First measurements of $\mathrm{ClOOCl}$ in the stratosphere: The coupling of $\mathrm{ClOOCl}$ and $\mathrm{ClO}$ in the Arctic polar vortex, J. Geophys. Res.-Atmos., 109(16), D03301, doi:10.1029/2003jd003811, 2004.

Tellinghuisen, J.: Precise equilibrium constants from spectrophotometric data: $\mathrm{BrCl}$ in $\mathrm{Br}_{2} / \mathrm{Cl}_{2}$ gas mixtures, J. Phys. Chem. A, 107, 753-757, doi:10.1021/jp027227w, 2003.

Theys, N., Van Roozendael, M., Hendrick, F., Fayt, C., Hermans, C., Baray, J.-L., Goutail, F., Pommereau, J.-P., and De Mazire, M.: Retrieval of stratospheric and tropospheric $\mathrm{BrO}$ columns from multi-axis DOAS measurements at Reunion Island $\left(21^{\circ} \mathrm{S}\right.$, $56^{\circ}$ E), Atmos. Chem. Phys., 7, 4733-4749, doi:10.5194/acp-74733-2007, 2007.

Thornton, B. F., Toohey, D. W., Avallone, L. M., Harder, H., Martinez, M., Simpas, J. B., Brune, W. H., and Avery, M. A.: In situ observations of $\mathrm{ClO}$ near the winter polar tropopause, J. Geophys. Res.-Atmos., 108(8), 8333, doi:10.1029/2002jd002839, 2003

Thornton, B. F., Toohey, D. W., Avallone, L. M., Hallar, A. G., Harder, H., Martinez, M., Simpas, J. B., Brune, W. H., Koike, M., Kondo, Y., Takegawa, N., Anderson, B. E., and Avery, M. A.: Variability of active chlorine in the lowermost Arctic stratosphere, J. Geophys. Res.-Atmos., 110(11), D22304, doi:10.1029/2004jd005580, 2005.

Tørnkvist, K. K., Arlander, D. W., and Sinnhuber, B. M.: Ground-based UV measurements of $\mathrm{BrO}$ and $\mathrm{OClO}$ over $\mathrm{Ny}$ Ålesund during winter 1996 and 1997 and Andøya during winter 1998/1999, J. Atmos. Chem., 43, 75-106, 2002.

Trolier, M., Mauldin, R. L., and Ravishankara, A. R.: Rate Coefficient for the Termolecular Channel of the Self-Reaction of ClO,
J. Phys. Chem., 94, 4896-4907, 1990.

Tung, K. K., Ko, M. K. W., Rodriguez, J. M., and Sze, N. D.: Are Antarctic ozone variations a manifestation of dynamics or chemistry?, Nature, 322, 811-814, 1986.

Vandaele, A. C., Hermans, C., Fally, S., Carleer, M., Merienne, M. F., Jenouvrier, A., Coquart, B., and Colin, R.: Absorption crosssections of $\mathrm{NO}_{2}$ : simulation of temperature and pressure effects, Journal of J. Quant. Spectros. Ra., 76, 373-391, 2003.

Vandaele, A. C., Fayt, C., Hendrick, F., Hermans, C., Humbled, F., Van Roozendael, M., Gil, M., Navarro, M., Puentedura, O., Yela, M., Braathen, G., Stebel, K., Tornkvist, K., Johnston, P., Kreher, K., Goutail, F., Mieville, A., Pommereau, J. P., Khaikine, S., Richter, A., Oetjen, H., Wittrock, F., Bugarski, S., Frieß, U., Pfeilsticker, K., Sinreich, R., Wagner, T., Corlett, G., and Leigh, R.: An intercomparison campaign of ground-based UV-visible measurements of $\mathrm{NO}_{2}, \mathrm{BrO}$, and $\mathrm{OClO}$ slant columns: Methods of analysis and results for $\mathrm{NO}_{2}$, J. Geophys. Res.-Atmos., 110(26), D08305, doi:10.1029/2004jd005423, 2005.

Vogel, B., Muller, R., Deshler, T., Grooss, J. U., Karhu, J., McKenna, D. S., Muller, M., Toohey, D., Toon, G. C., and Stroh, F.: Vertical profiles of activated $\mathrm{ClO}$ and ozone loss in the Arctic vortex in January and March 2000: In situ observations and model simulations, J. Geophys. Res.-Atmos., 108(19), 8334, doi:10.1029/2002jd002564, 2003.

von Hobe, M., Grooß, J.-U., Müller, R., Hrechanyy, S., Winkler, U., and Stroh, F.: A re-evaluation of the $\mathrm{ClO} / \mathrm{Cl}_{2} \mathrm{O}_{2}$ equilibrium constant based on stratospheric in-situ observations, Atmos. Chem. Phys., 5, 693-702, doi:10.5194/acp-5-693-2005, 2005.

von Hobe, M., Salawitch, R. J., Canty, T., Keller-Rudek, H., Moortgat, G. K., Groo, J.-U., Müller, R., and Stroh, F.: Understanding the kinetics of the $\mathrm{ClO}$ dimer cycle, Atmos. Chem. Phys., 7, 3055-3069, doi:10.5194/acp-7-3055-2007, 2007.

Vountas, M., Rozanov, V. V., and Burrows, J. P.: Ring effect: Impact of rotational Raman scattering on radiative transfer in earth's atmosphere, J. Quant. Spectros. Ra., 60, 943-961, 1998.

Wagner, T., Leue, C., Pfeilsticker, K., and Platt, U.: Monitoring of the stratospheric chlorine activation by Global Ozone Monitoring Experiment (GOME) OClO measurements in the austral and boreal winters 1995 through 1999, J. Geophys. Res.-Atmos., 106, 4971-4986, 2001.

Wagner, T., Wittrock, F., Richter, A., Wenig, M., Burrows, J. P., and Platt, U.: Continuous monitoring of the high and persistent chlorine activation during the Arctic winter 1999/2000 by the GOME instrument on ERS-2, J. Geophys. Res.-Atmos., 107, 8267, doi:10.1029/2001JD000466, 2002.

Wagner, T., Burrows, J. P., Deutschmann, T., Dix, B., von Friedeburg, C., Frieß, U., Hendrick, F., Heue, K.-P., Irie, H., Iwabuchi, H., Kanaya, Y., Keller, J., McLinden, C. A., Oetjen, H., Palazzi, E., Petritoli, A., Platt, U., Postylyakov, O., Pukite, J., Richter, A., van Roozendael, M., Rozanov, A., Rozanov, V., Sinreich, R., Sanghavi, S., and Wittrock, F.: Comparison of box-airmass-factors and radiances for Multiple-Axis Differential Optical Absorption Spectroscopy (MAX-DOAS) geometries calculated from different UV/visible radiative transfer models, Atmos. Chem. Phys., 7, 1809-1833, doi:10.5194/acp-7-1809-2007, 2007.

Wahner, A., Tyndall, G. S., and Ravishankara, A. R.: Absorption cross sections for $\mathrm{OClO}$ as a function of temperature in the wavelength range 240-480 nm, J. Phys. Chem., 91, 2734-2738, 1987. 
Wahner, A., Jakoubek, R. O., Mount, G. H., Ravishankara, A. R., and Schmeltekopf, A. L.: Remote sensing observations of nighttime $\mathrm{OClO}$ column during the Airborne Antarctic Ozone Experiment, 8 September 1987, J. Geophys. Res., 94, 11405-11411, 1989.

Wilmouth, D. M., Hanisco, T. F., Donahue, N. M., and Anderson, J. G.: Fourier Transform Ultraviolet Spectroscopy of the $\mathrm{A}^{2} \Pi_{3 / 2} \leftarrow \mathrm{X}^{2} \Pi_{3 / 2}$ Transition of BrO, J. Phys. Chem. A, 103, 8935-8945, 1999 .
Wittrock, F., Oetjen, H., Richter, A., Fietkau, S., Medeke, T., Rozanov, A., and Burrows, J. P.: MAX-DOAS measurements of atmospheric trace gases in Ny-Ålesund - Radiative transfer studies and their application, Atmos. Chem. Phys., 4, 955-966, doi:10.5194/acp-4-955-2004, 2004.

WMO: Scientific Assessment of Ozone Depletion: 2006, World Meteorological Organization, Geneva, 2007.

Yung, Y. L., Pinto, J. P., Watson, R. Z., and Sander, S. P.: Atmospheric Bromine and Ozone Perturbations in the Lower Stratosphere, J. Atmos. Sci., 37, 339-353, 1980. 